\title{
Validation of cleaning process of cardiac catheters and reuse in the hemodynamics sector of a hospital in Ponta Grossa, Parana, Brazil
}

\author{
M Gaspar ${ }^{1}$, CLD Silva ${ }^{2 *}$, CRB Bastos $^{3}$, JSD Nascimento ${ }^{2}$, VRD Maia ${ }^{4}$ \\ From International Conference on Prevention \& Infection Control (ICPIC 2011) \\ Geneva, Switzerland. 29 June - 2 July 2011
}

\section{Introduction / objectives}

Reprocessing single use devices is the process to be applied to hospital/medical objects which allows their reuse; in order to reuse them it is necessary to include steps in order to ensure that the catheters are clean, without organic matter, reducing the microbial load, pyrogens and biofilm. To develop and validate a cleaning protocol for objects from a cardiology sector in a hospital in Ponta Grossa, Parana, Brazil.

\section{Methods}

A quantitative and experimental study undertaken in February and March 2011 with a sample of 72 cardiac catheters. A protocol for cleaning tools and training with the nursing staff has been developed, using as a method to detect organic matter in the lumen, the Hemocheck ${ }^{\circledR}$, a tool that can detect from oug to $100 \mathrm{ug}$.

\section{Results}

In the beginning, we observed that the catheters were flushing with $1(1.38 \%)$ of the catheters had $100 \mathrm{ug}$ of matter in the lumen, 5 (6.94\%) had 10 ug of dust, 3 $(4.16 \%)$ of the catheters showed $1 \mathrm{ug}, 11$ (15.27\%) showed 0.1 ugof organic matter and $52(72.22 \%)$ with $0 \mu \mathrm{g}$ of dirt in the lumen; after 45 days conducting a systematic way of cleaning and tests in random days and times, there was not positivity of dirt in the catheter compared to results found previously.

\section{Conclusion}

The Infection Control Service and Materials Centrer of will need to implement the protocol, giving priority to

${ }^{2}$ Universidade Estadual de Ponta Grossa - Paranà, Ponta Grossa, Brazil Full list of author information is available at the end of the article patient safety, as the critical items such as the hemodynamic, by its nature and we need more care with this item.

\section{Disclosure of interest}

None declared.

\section{Author details \\ ${ }^{1}$ Departamento de Enfermagem e Saúde Pública, Ponta Grossa, Brazil. ${ }^{2}$ Universidade Estadual de Ponta Grossa - Paranà, Ponta Grossa, Brazil. ${ }^{3}$ Santa Casa de Misericórdia de Ponta Grossa, Ponta Grossa, Brazil. ${ }^{4}$ Hospital Regional de Ponta Grossa, Ponta Grossa, Brazil.}

Published: 29 June 2011

doi:10.1186/1753-6561-5-S6-P214

Cite this article as: Gaspar et al:: Validation of cleaning process of cardiac catheters and reuse in the hemodynamics sector of a hospital in Ponta Grossa, Parana, Brazil. BMC Proceedings 2011 5(Suppl 6):P214.

Submit your next manuscript to BioMed Central and take full advantage of:

- Convenient online submission

- Thorough peer review

- No space constraints or color figure charges

- Immediate publication on acceptance

- Inclusion in PubMed, CAS, Scopus and Google Scholar

- Research which is freely available for redistribution 